\title{
MTOR Gene Mutation
}

National Cancer Institute

\section{Source}

National Cancer Institute. MTOR Gene Mutation. NCI Thesaurus. Code C133686.

A change in the nucleotide sequence of the MTOR gene. 